\title{
SEROPREVALENCE OF Helicobacter pylori INFECTION IN CHRONIC CHAGASIC PATIENTS, AND IN THE RURAL AND URBAN POPULATION FROM UBERLÂNDIA, MINAS GERAIS, BRAZIL
}

Rubens Silva NASCIMENTO(1), Selma Regina Guerra VALENTE(2) \& Luiz Carlos Marques de OLIVEIRA(3)

\begin{abstract}
SUMMARY
As patients with chronic Chagas disease exhibit morphological and functional changes of the stomach (hypomotility and hypochlorhydria), malnutrition, immunological deficiency and high prevalence of peptic disease associated to Helicobater pylori infection, the purpose of this study was to evaluate if the prevalence of $\mathrm{H}$. pylori infection in chronic chagasic is higher than in nonchagasic individuals in the urban and rural population from Uberlândia, MG, Brazil. Serological determination of IgG antibodies to H. pylori was performed using a second-generation ELISA. Thus, 598 people were evaluated: 128 chagasic (CG), 222 non-chagasic living in urban area (U-NCG) and 248 non-chagasic living in rural area (R-NCG). Regarding the age range from 21 to 50 years, the prevalence of $H$. pylori infection in the CG $(85.1 \%)$ was significantly higher than in the U-NCG $(56.3 \%, \mathrm{p}<0.01)$ and the R-NCG $(67.4 \%, \mathrm{p}<0.05)$. In the patients over 50 years, the prevalence in the CG $(86.4 \%)$ was similar to the U-NCG $(78.8 \%)$ and R-NCG $(86.1 \%)$. Similar results were also found between the U-NCG and R-NCG for all age ranges, with prevalence rates of $29.1 \%$ and $35.3 \%$ for the age range from 5 to 13 years, and $47.2 \%$ and $40 \%$ for that from 14 to 20 years, respectively. We conclude that chagasic patients showed a higher seroprevalence of $H$. pylori infection than non-chagasic individuals, in the age range from 21 to 50 years, and that the prevalence of this infection was similar in the studied urban and rural non-chagasic population.
\end{abstract}

KEYWORDS: Chagas disease; Helicobacter pylori; Prevalence; Epidemiology; Minas Gerais; Brazil.

\section{INTRODUCTION}

Chagas disease is caused by the protozoan parasite Trypanosoma cruzi, which is transmitted to humans mainly by triatomine bugs ${ }^{7}$ and blood transfusion ${ }^{10}$. In the chronic Chagas disease, the patients can be asymptomatic and present conventional electrocardiogram as well as radiological studies of the heart and digestive tube without changes. This disease form is recognized as indeterminate ${ }^{2}$ and can develop to the cardiac (arrhytmias and/or congestive heart failure) and/or digestive (megaesophagus and/or megacolon) forms. In the stomach, the degeneration of the intra-mural ganglionic nerve cells causes a wide variety of motor and secretory disturbances of the organ ${ }^{24}$.

It has been demonstrated that individuals with chronic Chagas disease present high prevalence of peptic disease associated to Helicobacter pylori infection ${ }^{1,22,33}$. H. pylori is a Gram-negative spiral bacterium described in $1983^{37}$ and recognized as etiological agent of chronic gastritis, peptic ulcer and gastric cancer ${ }^{15}$. This microorganism is worldwide distributed with high prevalence in developing countries and the childhood is the most important period of acquisition of this infection, affecting mainly children with low socioeconomic level, and its horizontal transmission can occur by fecal-oral or oral-oral routes ${ }^{5,16}$.
Since no controlled study has been reported showing that chagasic patients have higher prevalence of $H$. pylori infection than non-chagasic individuals, the purpose of this study was to evaluate the prevalence of this infection in patients with chronic Chagas disease and in non-chagasic individuals living in urban or rural area of Uberlândia, state of Minas Gerais, a Southeast region of Brazil.

\section{PATIENTS AND METHODS}

We evaluated the prevalence of $H$. pylori infection in a total of 598 individuals aged 5 to 86 years, from which $322(53.8 \%)$ were male and 276 (46.2\%) female, from July 1997 to January 1999. From these, 128 had Chagas disease (chagasic group - CG), age ranging from 21 to 77 years and all of them were coming from a rural area. These patients were seen as in- or outpatients for a large range of complaints, except for dyspepsia as a major complaint, or were referred from the blood bank because of testing positive for Chagas disease. The 470 remaining individuals had negative serological results for Chagas disease and comprised the non-chagasic groups (NCG). From these, 222 were individuals living in the urban area (U-NCG) including students and blood donors of Hemocentro Regional de Uberlândia, and 248 were children from the rural schools and adults living in the rural area (R- 


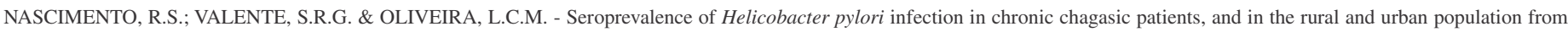
Uberlândia, Minas Gerais, Brazil. Rev. Inst. Med. trop. S. Paulo, 44(5):251-254, 2002.

NCG) of Uberlândia, MG. The groups were randomly selected. Due to differences in the prevalence of $H$. pylori infection in different age ranges, the groups were divided into subgroups according to age, as demonstrated in Table 1. Individuals from the urban area had a socioeconomic level higher than those from the rural area. The chagasic patients were also distributed according to the clinic form of disease, that is, digestive $(\mathrm{N}=$ $59)$, cardiac $(\mathrm{N}=42)$ or indeterminate $(\mathrm{N}=27)$. Informed consent was obtained from adult individuals and of the children's parents or responsible persons to participate in the study.

Table 1

Distribution of the individuals according to age in the different groups: chagasic (CG), non-chagasic living in urban area (U-NCG), and non-chagasic living in rural area (R-NCG) of Uberlândia, MG, Brazil

\begin{tabular}{lccc}
\hline Age $(\mathrm{yr})$ & \multicolumn{3}{c}{$\begin{array}{c}\text { Number of individuals } \\
\text { (mean age } \pm \text { standard deviation) }\end{array}$} \\
\hline $5-13$ & CG & U-NCG & R-NCG \\
$14-20$ & & $36(17.3 \pm 1.9)$ & $50(15.0 \pm 11.3)$ \\
$21-50$ & $47(40.2 \pm 7.0)$ & $48(33.4 \pm 7.5)$ & $43(34.6 \pm 8.1)$ \\
$>50$ & $81(61.6 \pm 7.3)$ & $52(63.3 \pm 10.0)$ & $36(62.0 \pm 9.2)$ \\
\hline Total & 128 & 222 & 248 \\
\hline
\end{tabular}

Serological tests for Chagas disease included the indirect immunofluorescence reaction and the immunoenzymatic assay (ELISA), considering as chagasic the individuals with both positive tests and excluding those with only one single positive test, thus eliminating positive or negative false results. Serological diagnosis of $H$. pylori infection was carried out through the determination of $\mathrm{IgG}$ antibodies to H. pylori using a second-generation ELISA (Alexon Inc., Sunnyvale, California, USA), according to manufacturer's instructions. Such method was chosen due to its easiness in population studies.

Statistical analysis of the prevalence of $H$. pylori infection in the different subgroups was performed by non-parametric methods, including the chi-square test and Fisher's exact test. The level of significance was set at $\mathrm{p}<0.05$.

\section{RESULTS}

When comparing the various subgroups in the age range from 21 to 50 years, the prevalence of $H$. pylori infection in the chagasic subgroup $(85.1 \%)$ was significantly higher than that of the urban non-chagasic $(56.3 \%, \mathrm{p}<0.01)$ and the rural non-chagasic $(67.4 \%, \mathrm{p}<0.05)$ subgroups. Among the individuals over 50 years, the prevalence in the CG $(86.4 \%)$ was similar to the U-NCG (78.8\%) and R-NCG (86.1\%). Similar results were also found between the U-NCG and R-NCG for all age ranges, with prevalence rates of $29.1 \%$ and $35.3 \%$ for the age range from 5 to 13 years and $47.2 \%$ and $40 \%$ for that from 14 to 20 years, respectively (Table 2). Similar H. pylori infection rates were also found among the chagasic patients with digestive (49/59 - 83\%), cardiac (37/42 - 88.1\%) and indeterminate $(24 / 27-88.9 \%)$ forms of the disease.
Table 2

Seroprevalence of Helicobacter pylori infection in chronic chagasic patients (CG) and in the non-chagasic rural (R-NCG) and urban (U-NCG) population

\begin{tabular}{|c|c|c|c|}
\hline \multirow[t]{2}{*}{ Age (yr) } & \multicolumn{3}{|c|}{ Seropositivity $^{a}$} \\
\hline & CG & U-NCG & R-NCG \\
\hline $5-13$ & & $25 / 86(29.1 \%)$ & $42 / 119(35.3 \%)$ \\
\hline $14-20$ & & $17 / 36(47.2 \%)$ & $20 / 50(40.0 \%)$ \\
\hline $21-50$ & $40 / 47(85.1 \%)^{b}$ & $27 / 48(56.3 \%)$ & $29 / 43(67.4 \%)$ \\
\hline$>50$ & $70 / 81(86.4 \%)$ & $41 / 52(78.8 \%)$ & $31 / 36(86.1 \%)$ \\
\hline
\end{tabular}

$a$ : determined by ELISA; $b$ : $\mathrm{p}<0.01(\mathrm{CG}>\mathrm{U}-\mathrm{NCG})$ and $\mathrm{p}<0.05(\mathrm{CG}>\mathrm{R}-$ NCG) determined by the chi-square test or Fisher's exact test.

\section{DISCUSSION}

The rural origin of the chagasic patients, where factors such as low socioeconomic level, precarious living conditions, and ingestion of untreated water, especially during childhood, which are considered as important determinants for the risk of $H$. pylori infection ${ }^{12}$, did not appear to be responsible for the higher prevalence of this infection in the chagasic patients, aged 21 to 50 years, as compared to rural non-chagasic subgroup from same age range. However, this difference should be carefully analyzed, since the $\mathrm{p}$ value found $(\mathrm{p}=0.047)$ in the used statistical tests represented a borderline value. On the other hand, H. pylori when gaining entry to the stomach of chagasic patients could encounter favorable conditions for its installation, such as hypochlorhydria, hypomotility, malnutrition and immunological deficiency.

Hypochlorhydria, a probable facilitating factor of $H$. pylori infection ${ }^{19}$, has been described in chagasic patients and can be due to a decreased sensitivity of the parietal cells, as a consequence of the destruction of intramural innervation ${ }^{13,24,34}$ which is described in these individuals ${ }^{8}$.

The neuronal destruction of the gastric intramural plexum in patients with chronic Chagas disease can produce gastric stasis ${ }^{14,24}$, which in turn might predispose to bacterial overgrowth into the stomach and likely to H. pylori infection ${ }^{9}$.

The caloric-proteic malnutrition often found in patients with the digestive form of Chagas disease is the most frequent cause of secondary immunodeficiency, compromising both the specific and the non-specific compartments of the immune response ${ }^{36}$. In chronic chagasic patients, several immunological changes have been described such as leukopenia, depressed chemotactic activity of neutrophils and lymphopenia ${ }^{35}$, which could lead to an increased susceptibility to $H$. pylori infection in these individuals. In addition, at least in children, malnutrition also can produce hypochlorhydria, and this state may predispose to H. pylori infection ${ }^{5}$.

The fact that a higher prevalence of seropositivity for $H$. pylori infection was not found in chagasic patients with the digestive form as compared to the cardiac and indeterminate forms of the disease was not surprising. In our previous studies ${ }^{22}$, a high prevalence of $H$. pylori infection was found in patients with the indeterminate form of Chagas 


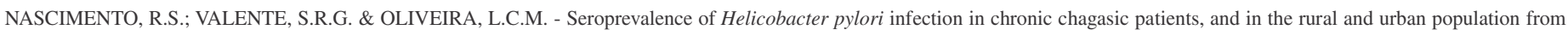
Uberlândia, Minas Gerais, Brazil. Rev. Inst. Med. trop. S. Paulo, 44(5):251-254, 2002.

disease, thus proposing the present study. The majority of studies that evaluated motility and/or gastric secretion changes in chagasic patients were performed in patients with the digestive form of the disease, making difficult this discussion. However, it is known that a patient presenting a determinate form of Chagas disease can also present lesions in other systems due to the criteria used to characterize the clinic form of the disease. Accordingly, in our previous studies, an important decrease in the pancreatic neuronal population was observed in patients with the cardiac form of the disease ${ }^{29}$, and insulin hyposecretion after a glicose stimulus was found in a group of chagasic patients presenting the cardiac or indeterminate or digestive forms ${ }^{23}$. In addition, the impairment of the cell-mediated immune response has been described even in the indeterminate form of Chagas disease $\mathrm{e}^{4}$ and if gastric motility changes could occur as already described for the esophagus in this disease form ${ }^{18}$, such facts could justify the similar prevalence of $H$. pylori infection found in the different forms of the disease in our study.

Similarly, it has been described that patients with diabetes mellitus also present a higher prevalence of $H$. pylori infection, which could be related to reduced gastric motility as a consequence of the autonomic neuropathy ${ }^{27,28}$ and/or to humoral and cellular immunosuppression often found in these individuals ${ }^{20}$.

Although the mean age of the chagasic patients from 21 to 50 years was higher than that in the urban and rural non-chagasic groups (Table 1), this fact did not seem to have influence on the results, since from seven chagasic patients with negative serology to $H$. pylori in that group, six individuals were between 39 and 47 years of age.

Regarding the age range over 50 years, a high prevalence of $H$. pylori infection was found and there was no significant difference among the studied subgroups. It is believed that this infection is acquired mainly in childhood, and as it usually passes undetected, the individuals could remain infected for all life $\mathrm{e}^{25,31}$. Therefore, in developed countries, the high prevalence of this infection in individuals over 60 years and the low incidence in young and children is justified by the current improvement of the socioeconomic conditions ${ }^{26,31}$. This fact has also been observed, at least in some areas, in Brazil ${ }^{21}$. However, it is important emphasize that hypochlorhydria ${ }^{11}$, decreased gastric motility with consequent delay in liquid emptying ${ }^{17}$, depressed immune responses ${ }^{6}$ as well as decline in the immune function of the lamina propria lymphocytes from the intestinal epithelium ${ }^{3}$ have been reported with advancing age.

When analyzing the same age ranges, there was no significant difference in the prevalence of $H$. pylori infection among the non-chagasic individuals living in rural or urban areas.

In Brazil, there are few studies on the prevalence of $H$. pylori infection. High prevalence of this infection associated to low socioeconomic level, deficiency of basic sanitation and crowded living conditions, was described in a rural population coming from the centralsouthern region of the state of Mato Grosso, showing rates of $77.5 \%$ in the age range from 10 to 19 years, $77.2 \%$ from 20 to 49 years, and $91.8 \%$ in individuals over 50 years ${ }^{32}$. In a study performed among children with low socioeconomic level in Belo Horizonte, capital of the state of Minas Gerais, a lower prevalence of this infection was found $(39.8 \%$ in children aged from 6 to 14 years and $64.3 \%$ in the 15 - to $18-\mathrm{yr}$ age range), probably due to improved socioeconomic and sanitation conditions of this population ${ }^{21}$. In another study, also in Belo Horizonte ${ }^{30}$, showed that the prevalence of this infection in the rural area $(71.9 \%$ in children and $89.8 \%$ in adults) was significantly higher than that observed in the urban area (43.3\% in children and $65.8 \%$ in adults).

The prevalence of $H$. pylori infection in our community was lower than those described in the above mentioned reports, probably reflecting the socioeconomic and sanitary conditions of this municipal area: in the rural area, houses have electrical energy, children have access to education and hygiene notions, and it is frequent the use of bathroom and water taps, although coming from cisterns.

The results of the present study showed a higher seroprevalence of H. pylori infection in patients with chronic Chagas disease than in nonchagasic individuals, in the age range from 21 to 50 years, in the studied population. Nevertheless, due to the borderline results between the CG and the R-NCG obtained in the statistical analysis, additional studies using other diagnostic methods should be conducted in other populations in order to establish definitely such association. In addition, it can be concluded that the seroprevalence of $H$. pylori infection is similar in the studied urban and rural non-chagasic population.

\section{RESUMO}

\section{Soroprevalência de infecção pelo Helicobacter pylori em pacientes chagásicos crônicos e na população urbana e rural de Uberlândia, Minas Gerais, Brasil}

Como pacientes na fase crônica da doença de Chagas podem ter alterações morfológicas e funcionais do estômago (hipomotilidade e hipocloridria), desnutrição, deficiência imunológica e altas prevalências de doença péptica associada à infecção pelo $H$. pylori, o objetivo deste estudo foi avaliar se a prevalência desta infecção em chagásicos crônicos é maior do que em indivíduos não chagásicos, na população urbana e rural de Uberlândia, MG, Brazil. Determinação sorológica de anticorpos IgG para o $H$. pylori foi realizada utilizando um teste ELISA de segunda geração. Assim, avaliamos 598 pessoas: 128 chagásicos (GC), 222 não chagásicos moradores da área urbana (GNC-U) e 248 não chagásicos moradores da área rural (GNC-R). Na faixa etária de 21 a 50 anos a prevalência de infecção pelo $H$. pylori no $\mathrm{GC}(85,1 \%)$ foi significativamente maior do que no GNC-U $(56,3 \%, \mathrm{p}<0,01)$ e do que no GNC-R $(67,4 \%, \mathrm{p}<0,05)$. Nos indivíduos acima de 50 anos, a prevalência no GC $(86,4 \%)$ foi semelhante ao GNC-U $(78,8 \%)$ e GNCR $(86,1 \%)$. Resultados semelhantes também foram encontrados entre o GNC-U e GNC-R para todas as faixas etárias, com prevalências de 29,1\% e 35,3\% para a faixa etária de 5 a 13 anos e $47,2 \%$ e $40 \%$ naquela de 14 a 20 anos, respectivamente. Concluímos que indivíduos com doença de Chagas crônica mostraram mais alta soroprevalência de infecção pelo H. pylori do que indivíduos não chagásicos, na faixa etária de 21 a 50 anos, e que a soroprevalência desta infecção foi semelhante na população não chagásica urbana e rural.

\section{REFERENCES}

1. BARBOSA,A.J.A.; QUEIROZ, D.M.M.; NOGUEIRA, A.M.M.F. et al. - Chronic gastritis and Helicobacter pylori in digestive form of Chagas' disease. Rev. Inst. Med. trop. S. Paulo, 35: 117-121, 1993 


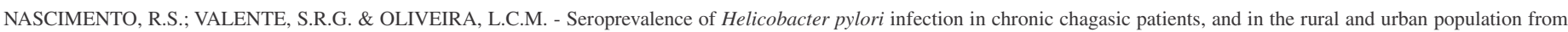
Uberlândia, Minas Gerais, Brazil. Rev. Inst. Med. trop. S. Paulo, 44(5):251-254, 2002.

2. BARRETTO, A.C.P. \& IANNI, B.M. - A forma indeterminada da moléstia de Chagas: conceito e implicações médico-legais. Rev. Soc. Cardiol. (S. Paulo), 4: 129-132, 1994.

3. BEHARKA, A.A.; PAIVA, S.; LEKA, L.S. et al. - Effect of age on the gastrointestinalassociated mucosal immune response of humans. J. Geront. A biol. Sci. med. Sci., 56: B218-B223, 2001.

4. BOTTASSO, O.A.; INGLEDEW, N.; KENI, M. et al. - Cellular immune response to common mycobacterial antigens in subjects seropositive for Trypanosoma cruzi. Lancet, 344: 1540-1541, 1994.

5. CAVE, D.R. - How is Helicobacter pylori transmitted? Gastroenterology, 113 (suppl. 6): S9-S14, 1997.

6. CASTLE, S.C. - Clinical relevance of age-related immune dysfunction. Clin. infect. Dis., 31: 578-585, 2000.

7. CHAGAS, C. - Nova tripanozomiaze humana. Estudos sobre a morfolojia e o ciclo evolutivo do Schizotrypanum cruzi $\mathrm{n}$. gen., n. sp., ajente etiolojico de nova entidade morbida do homem. Mem. Inst. Oswaldo Cruz, 1: 159-218, 1909.

8. COSTA, R.B. \& ALCÂNTARA, F.G. - Gastropatia chagásica crônica. Rev. bras. Med., 22: 667-671, 1965

9. FOCK, K.M.; KHOO, T.K.; CHIA, K.S. \& SIM, C.S. - Helicobacter pylori infection and gastric emptying of indigestible solids in patients with dysmotility-like dyspepsia. Scand. J. Gastroent., 32: 676-680, 1997.

10. FREITAS, J.L.P.; BIANCALANA, A.; AMATO-NETO, V. et al. - Primeiras verificações de transmissão acidental da moléstia de Chagas ao homem por transfusão da sangue. Rev. paul. Med., 40: 36-40, 1952

11. GROSSMAN, M.I.; KIRSNER, J.B. \& GILLESPIE, I.E. - Basal and histalog-stimulated gastric secretion in control subjects and in patients with peptic ulcer or gastric cancer. Gastroenterology, 45: 14-26, 1963.

12. KLEIN, P.D.; GRAHAM, D.Y.; GAILLOUR, A.; OPEKUN, A.R. \& SMITH, E.O. Water source as risk factor for Helicobacter pylori infection in Peruvian children. Gastrointestinal Physiology Working Group. Lancet, 337: 1503-1506, 1991.

13. LEÃO, G.J.C.; ZATERKA, S.; NEVES, D.P. \& BETTARELLO, A. - Acid secretion in patients with Chagas' disease. Acta gastroent. lat-amer., 11: 273-278, 1981.

14. LOPASSO, F.P.; PINTO Jr., P.E.; GAMA-RODRIGUES, J.J. \& PINOTTI, H.W. - Estudo do esvaziamento gástrico de partículas sólidas e digeríveis marcadas com ${ }^{99 \mathrm{~m}} \mathrm{Tc}$ na gastropatia chagásica crônica. GED, 4: 72-76, 1985.

15. MARSHALL, B.J. - Helicobacter pylori. Amer. J. Gastroent., 89 (suppl. 8): S116S128, 1994.

16. MENDALL, M.A. \& NORTHFIELD, T.C. - Transmission of Helicobacter pylori infection. GUT, 37: 1-3, 1995.

17. MOORE, J.G.; TWEEDY, C.; CHRISTIAN, P.E. \& DATZ, F.L. - Effect of age on gastric emptying of liquid-solid meals in man. Dig. Dis. Sci., 28: 340-344, 1983.

18. MORAES-FILHO, J.P.P.; MORAES, T.A.B.P.P.; FELIX, V.N.; PEREIRA-BARRETO, A.C. \& BETTARELLO, A. - Esophageal manometry and vectorcardiography study of asymptomatic patients with Chagas' disease. Rev. Inst. Med. trop. S. Paulo, 30: 406-410, 1988.

19. MORRIS, A. \& NICHOLSON, G. - Ingestion of Campylobacter pyloridis causes gastritis and raised fasting gastric pH. Amer. J. Gastroent., 82: 192-199, 1987.

20. OLDENBURG, B.; DIEPERSLOOT, R.J.A. \& HOEKSTRA, J.B.L. - High seroprevalence of Helicobacter pylori in diabetes mellitus patients. Dig. Dis. Sci., 41: 458-461, 1996.
21. OLIVEIRA, A.M.R.; QUEIROZ, D.M.M.; ROCHA, G.A. \& MENDES, E.N. Seroprevalence of Helicobacter pylori infection in children of low socioeconomic level in Belo Horizonte, Brazil. Amer. J. Gastroent., 89: 2201-2204, 1994.

22. OLIVEIRA, L.C.M.; BUSO, A.G.; SIQUEIRA FILHO, L. et al. - Peptic disease and Helicobacter pylori are highly prevalent in patients with the indeterminate form of Chagas' disease: report of 21 cases. Rev. Inst. Med. trop. S. Paulo, 39: 209-212, 1997.

23. OLIVEIRA, L.C.M.; JULIANO, Y.; NOVO, N.F. \& NEVES, M.M. - Blood glucose and insulin response to intravenous glucose by patients with chronic Chagas' disease and alcoholism. Braz. J. med. biol. Res., 26: 1187-1190, 1993.

24. PADOVAN, W.; MENEGHELLI, U.G. \& GODOY, R.A. - Gastric secretory and motility studies in chronic chagasic patients. Amer. J. dig. Dis., 22: 618-622, 1977.

25. PARSONNET, J. - The incidence of Helicobacter pylori infection. Aliment. Pharmacol. Ther., 9 (suppl. 2): 45-51, 1995.

26. PARSONNET, J.; BLASER, M.J.; PEREZ-PEREZ, G.I.; HARGRETT-BEAN, N. \& TAUXE, R.V. - Symptoms and risk factors of Helicobacter pylori infection in a cohort of epidemiologists. Gastroenterology, 102: 41-46, 1992.

27. PERDICHIZZI, G.; BOTTARI, M.; PALLIO, S. et al. - Gastric infection by Helicobacter pylori and antral gastritis in hyperglycemic obese and in diabetic subjects. New Microbiol., 19: 149-154, 1996.

28. PERSICO, M.; SUOZZO, R.; DE SETA, M. et al. - Non-ulcer dyspepsia and Helicobacter pylori in type 2 diabetic patients: association with autonomic neuropathy. Diabet. Res. clin. Pract., 31: 87-92, 1996.

29. ROCHA, A.; OLIVEIRA, L.C.M.; ALVES, R.S. \& LOPES, E.R. - Despopulação neuronal pancreática em chagásicos crônicos. Rev. Soc. bras. Med. trop., 31: 43-49, 1998.

30. ROCHA, G.A.; OLIVEIRA, A.M.R.; QUEIROZ, D.M.M.; MOURA, S.B. \& MENDES, E.N. - Prevalence of Helicobacter pylori infection in two different populations from Minas Gerais, Brazil. Amer. J. Gastroent., 89: 1313, 1994.

31. ROWLAND, M. - Transmission of Helicobacter pylori: is it all child's play? Lancet, 355: 332-333, 2000.

32. SOUTO, F.J.D.; FONTES, C.J.F.; ROCHA, G.A. et al. - Prevalence of Helicobacter pylori infection in a rural area of the state of Mato Grosso, Brazil. Mem. Inst. Oswaldo Cruz, 93: 171-174, 1998.

33. TRONCON, L.E.A.; BARBOSA, A.J.A.; CARVALHAIS, J.N. \& ROMANELLO, L.M.F. - Lower density of antral somatostatin-immunoreactive cells in the digestive form of chronic Chagas' disease. Braz. J. med. biol. Res., 29: 1449-1454, 1996.

34. TRONCON, L.E.A.; OLIVEIRA, R.B.; MENEGHELLI, U.G.; DANTAS, R.O. \& GODOY, R.A. - Plasma gastrin and gastric acid responses to insulin hypoglycemia in Chagas' disease. Braz. J. med. biol. Res., 18: 273-278, 1985.

35. VOLTARELLI, J.C.; DONADI, E.A.; CARVALHO, I.F. \& FALCÃO, R.P. - Lymphocyte subpopulations and neutrophil function in chronic human Chagas' disease. Rev. Inst. Med. trop. S. Paulo, 32: 240-248, 1990.

36. VOLTARELLI, J.C. \& FALCÃO, R.P. - Imunodeficiências secundárias. Medicina (Ribeirão Preto), 28: 329-377, 1995.

37. WARREN, J.R. \& MARSHALL, B. - Unidentified curved bacilli on gastric epithelium in active chronic gastritis. Letter. Lancet, 1: 1273-1275, 1983.

Received: 03 May 2002

Accepted: 30 July 2002 